\title{
RHINOVIRUS INFECTIONS IN CHRONIC BRONCHITIS: ISOLATION OF EIGHT POSSIBLY NEW RHINOVIRUS SEROTYPES
}

\author{
E. J. Stott*, N. R. Grist and Margaret B. Eadie \\ Regional Virus Laboratory, Ruchill Hospital, Glasgow, Department of Infectious Diseases, \\ University of Glasgow, and the Common Cold Research Unit, Salisbury
}

RHINOVIRUSES were isolated from 25 per cent. of patients with exacerbations of chronic bronchitis studied in Glasgow (Eadie, Stott and Grist, 1966) and from 14 per cent. of chronic bronchitics with exacerbations investigated in Sheffield (Stenhouse, 1967). Myxovirus and adenovirus infections have also been associated with smaller proportions of exacerbations in serological studies (Stark, Heath and Curwen, 1965; Ross et al., 1966). We wished to know whether the rhinoviruses that cause lower respiratory symptoms in bronchitics are similar to those isolated from upper respiratory illnesses of normal adults and children and whether the serological response that they induce is greater in exacerbations than in milder infections. This paper describes the isolation of the rhinoviruses and the extent and duration of neutralising antibody responses to them. It attempts to characterise and identify the virus strains isolated and to determine their similarity to rhinoviruses isolated from other types of respiratory illness.

\section{MATERIALS AND METHODS}

Population studied. Fifteen patients with chronic bronchitis were studied for $2 \frac{1}{2} \mathrm{yr}$ between January 1962 and June 1964 as described previously (Eadie et al.) and a further 29 patients were studied by similar methods between January and April, 1965. A throat swab or nasal washing or both were collected during each episode of respiratory infection, and whenever possible sputum was also obtained. A second and third series of specimens were collected at 3-4-day intervals from some of the patients studied between January and April 1965.

Tissue culture cells. Cell strains of human embryonic fibroblasts included WI-38 and various strains derived locally from kidney and lung tissue by the methods of Hayflick and Moorhead (1961). All these cells were grown and maintained as described previously (Stott and Walker, 1967).

Virus isolation and characterisation. The methods used for virus isolation have been described previously (Grist et al., 1966). Chloroform stability of rhinoviruses was established by shaking $0.9 \mathrm{ml}$. of virus with $0.1 \mathrm{ml}$. of chloroform for $5 \mathrm{~min}$. at room temperature. A pool of the chloroform-sensitive herpes simplex virus with a titre of $104 \cdot 8$ TCD50 per $0.2 \mathrm{ml}$ was completely inactivated by this treatment. Acid lability was determined by incubating $0.4-\mathrm{ml}$ volumes of virus in (i) an equal volume of citrate-citric acid buffer at $p \mathrm{H} \mathrm{4}$, and in (ii) an equal volume of phosphate buffer at $p \mathrm{H} 7$ (as control) for $1 \mathrm{hr}$ at $37^{\circ} \mathrm{C}$. The virus-buffer mixtures were then brought to neutral $p \mathrm{H}$ with phosphate buffer and titrated. The acid-stable echovirus 7 was always included as a control and showed no difference in titre after acid treatment. Evidence for nucleic acid type was obtained by

* Present address: Common Cold Research Unit, Coombe Road, Salisbury, Wilts. Received 17 Jan. 1968; accepted 8 Mar. 1968.

J. MED. MICROBIOL.-VOL. I (1968) 
titrating virus in the presence and in the absence of bromodeoxyuridine at a concentration of $20 \mu \mathrm{g}$ per ml. Size was estimated by filtration of the virus through Gradocol membranes of $53 \mathrm{~m} \mu$ average pore diameter or Millipore filters of $50 \mathrm{~m} \mu$ pore size.

Virus titration. $\mathbf{0} \cdot 1$ or $\mathbf{0 . 2}-\mathrm{ml}$ volumes of serial ten-fold dilutions of virus were inoculated into groups of 3-5 tissue culture tubes. These were examined for cytopathic effects after 7 days and the 50 per cent. end-point calculated by the method of Kärber (1931).

Virus identification. Attempts were made to identify the rhinoviruses by neutralisation tests with antisera prepared against rhinovirus types 1A-20, 24 and 26-55 (Kapikian et al., 1967). In these tests, $0.1 \mathrm{ml}$ of serum containing at least 20 antibody units was mixed with $0.1 \mathrm{ml}$ of virus diluted to contain 30-100 TCD50 and incubated at room temperature for $1 \frac{1}{2} \mathrm{hr}$. The mixtures were then inoculated into tubes of tissue cultures which were observed for evidence of virus neutralisation.

TABLE I

Clinical diagnoses and virus isolations in 87 respiratory episodes in 24 patients with chronic bronchitis

\begin{tabular}{|c|c|c|c|c|}
\hline \multirow{2}{*}{ Clinical diagnosis } & \multirow{2}{*}{$\begin{array}{l}\text { Number of } \\
\text { episodes } \\
\text { investigated }\end{array}$} & \multicolumn{3}{|c|}{ Virus isolated ${ }^{*}$} \\
\hline & & RH & PF & HS \\
\hline $\begin{array}{l}\text { Cold }(a) \text { immediately preceded or followed } \\
\text { by exacerbation } \\
\quad(b) \text { without exacerbation } \\
\text { Influenza-like illness } \\
\text { Exacerbation without cold }\end{array}$ & $\begin{array}{r}23 \\
7 \\
30\end{array}$ & $\begin{array}{l}1 \\
0 \\
1\end{array}$ & $\begin{array}{l}0 \\
1 \\
0\end{array}$ & $\begin{array}{l}0 \\
0 \\
0\end{array}$ \\
\hline Totals & 87 & 14 & 1 & 1 \\
\hline
\end{tabular}

* $\mathrm{RH}=\mathrm{Rhinovirus} ; \mathrm{PF}=$ parainfluenza type $1 ; \mathrm{HS}=$ herpes simplex.

Antibody titration. Sera were inactivated at $56^{\circ} \mathrm{C}$ for $30 \mathrm{~min}$. Serial two-fold dilutions of sera in $0.25-\mathrm{ml}$ volumes were mixed with equal volumes of virus containing 10-100 TCD50. After $1 \frac{1}{2} \mathrm{hr}$ at room temperature, $0.2 \mathrm{ml}$ of each mixture was inoculated into each of two tubes of tissue culture. The 50 per cent. neutralisation end-point was calculated by the method of Kärber.

Preparation of antisera. Virus was grown in $250-\mathrm{ml}$ centrifuge bottles that contained a monolayer of human embryonic kidney fibroblasts around the entire inner circumference. When approximately 75 per cent. of the cells had degenerated, the bottles were frozen and thawed, the contents centrifuged at 5000 r.p.m. for $20 \mathrm{~min}$. and the supernatant fluid stored at $-70^{\circ} \mathrm{C}$. These virus pools had titres between $10^{4.5}$ and 106.5 TCD50 per ml. Blood $(5 \mathrm{ml})$ was collected from guinea-pigs weighing 800-1200 g which were then given intramuscularly in the hind leg $1 \mathrm{ml}$ of an emulsion of equal parts of virus and Freund's incomplete adjuvant (Difco). Two weeks later the animals received a second similar inoculation and after a further $3 \mathrm{wk} 1 \mathrm{ml}$ of virus was injected intramuscularly without adjuvant. Five days later the animals were exsanguinated.

\section{RESULTS \\ Virus isolation}

Eighty-seven acute respiratory episodes occurred in 24 of 44 chronic bronchitic patients and these were investigated during the two periods of study (see Methods). The clinical types of these episodes and the viruses isolated from them are shown in table I. Eighty nasal washings, 92 throat swabs and 66 
TABLE II

Details of 14 rhinovirus infections in 9 patients with chronic bronchitis

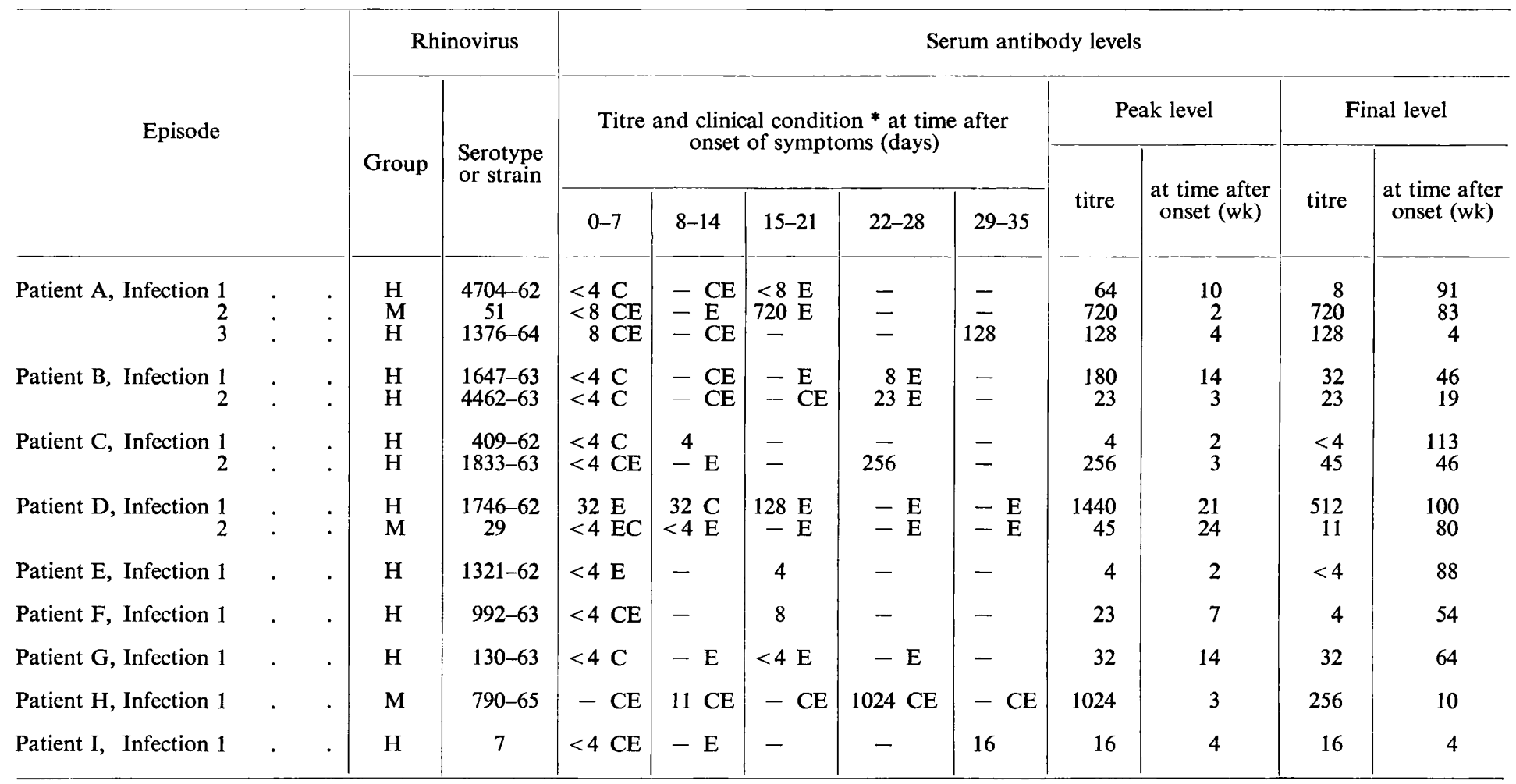


specimens of sputum were examined. Rhinoviruses were isolated in 14 episodes, and a para-influenza virus and a herpes simplex virus each in one incident. Three of the rhinoviruses were $M$ strains and 11 were $H$ strains.

Rhinoviruses were isolated from seven specimens of sputum collected during six separate episodes in five patients; on four occasions a throat swab taken at about the same time did not yield a rhinovirus. The titres of rhinovirus in the

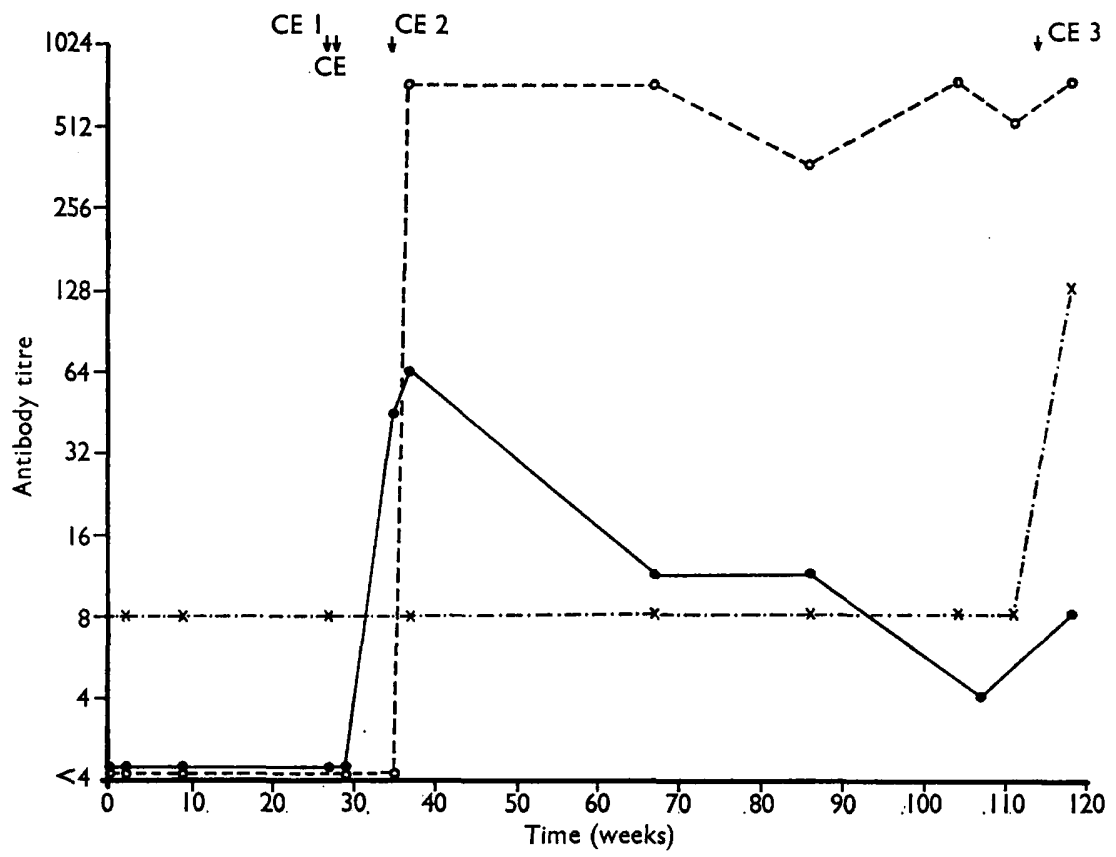

FIgURE.-Antibody responses of patient $A$ to rhinovirus infections 1, 2 and 3. Note (a) persistence of antibody after infections 1 and 2 for over $80 \mathrm{wk}$ with no evidence of reinfection in the intervening period (similar observations were made in patients $\mathrm{B}, \mathrm{C}, \mathrm{D}, \mathrm{F}$ and $\mathrm{G}$ ); and $(b)$ the absence of any significant heterologous antibody responses during the three infections. Similar observations were made in patients $B, C$ and $D$.

- Antibody response to infection 1 with rhinovirus 4704-62;

$\mathrm{O}-. \mathrm{O}=$ antibody response to infection 2 with rhinovirus type 51 ;

$x \cdot-\cdot x=$ antibody response to infection 3 with rhinovirus 1376-64.

$\mathrm{C}=$ Week of onset of cold;

$\mathbf{E}=$ week of onset of exacerbation.

Antibody titres expressed as reciprocal of highest dilution of serum that completely neutralised virus in 50 per cent. of tubes inoculated.

sputum specimens collected on these four occasions were $10^{2 \cdot 1}, 10^{2 \cdot 1}, 10^{2 \cdot 4}$ and $10^{3 \cdot 1}$ TCD50 per ml when assayed in human embryonic kidney fibroblasts. Titres in the other three specimens were $10^{2 \cdot 1}, 10^{4 \cdot 4}$ and $10^{5 \cdot 1}$ TCD50 per ml.

\section{Serological results}

The neutralising antibody titres of sera from the 9 patients who between them had 14 rhinovirus infections are shown in table II and the detailed antibody responses of patient $\mathrm{A}$ to her three infections are shown in the figure. 
Serum was collected less than 7 days after the onset of symptoms in 13 of the 14 infections; in two of these 13, antibody against the infecting rhinovirus was present, but in both cases the infection was associated with an exacerbation. Infection 1 of patient $C$ and infection 1 of patient $E$ were the only ones that did not stimulate more than a four-fold rise in antibody titre; the former was the only rhinovirus infection not associated with an exacerbation and the latter was the only one in which no upper respiratory tract symptoms were evident.

There were five infections (infection 1 of patients A, B, D, F and G) in which the serum samples taken between 15 and 28 days after the onset of symptoms showed only a small rise in neutralising antibodies or none at all. However,

TABLE III

Cross-neutralisation tests with 10 rhinovirus strains

\begin{tabular}{|c|c|c|c|c|c|c|c|c|c|c|}
\hline \multirow{2}{*}{ Virus tested * } & \multicolumn{10}{|c|}{$\begin{array}{l}\text { Highest effective dilution of neutralising antiserum prepared } \\
\text { against rhinovirus of strain }\end{array}$} \\
\hline & 409 & 1321 & 1746 & 4704 & 130 & 992 & 1647 & 1833 & 4462 & 1376 \\
\hline $\begin{array}{r}409-62 \\
1321-62 \\
1746-62 \\
4704-62 \\
130-63 \\
992-63 \\
1647-63 \\
1833-63 \\
4462-63 \\
1376-64\end{array}$ & \begin{tabular}{c|}
720 \\
- \\
1024 \\
- \\
$=$ \\
$=$ \\
$=$ \\
$=$
\end{tabular} & $\begin{array}{l}\overline{512} \\
\overline{-} \\
\bar{z} \\
\bar{z} \\
\bar{z} \\
=\end{array}$ & $\begin{array}{l}256 \\
- \\
= \\
= \\
= \\
= \\
= \\
=\end{array}$ & $\begin{array}{l}- \\
- \\
360 \\
= \\
- \\
= \\
- \\
-\end{array}$ & $\begin{array}{l}- \\
\overline{-} \\
\overline{\overline{10}} \\
512 \\
- \\
\overline{-} \\
-\end{array}$ & $\begin{array}{l}- \\
- \\
- \\
512 \\
720 \\
- \\
- \\
-\end{array}$ & $\begin{array}{l}- \\
= \\
= \\
= \\
\overline{360} \\
= \\
=\end{array}$ & $\begin{array}{l}\overline{-} \\
\overline{-} \\
\overline{-} \\
\overline{-} \\
\overline{512} \\
\overline{-}\end{array}$ & $\begin{array}{l}- \\
- \\
- \\
- \\
- \\
- \\
\overline{720}\end{array}$ & $\begin{array}{l}= \\
= \\
= \\
= \\
= \\
\overline{-} \\
360\end{array}$ \\
\hline
\end{tabular}

* Virus doses were 32-320 TCD50 per 0.1 ml.

+ Titres expressed as reciprocal of highest dilution of serum that completely neutralised virus in 50 per cent. of tubes inoculated.

$-=$ No neutralisation at a dilution of 1 in 16 .

the titres of serum samples taken between 7 and 21 wk after the onset of symptoms were 10- to 22 -fold higher, except in the case of patient $F$ who had produced only a three-fold increase by then. Three of these five infections were associated with colds that were followed by exacerbations 1-3 wk after the onset of the original cold.

After ten of the 14 rhinovirus infections, the patients' antibody levels were followed for periods between 46 and $113 \mathrm{wk}$. When an infection had induced an antibody titre greater than 4 , antibody against the infecting rhinovirus was still present in the final serum sample and often at a high titre, although intervening serum samples showed no rise in titre that suggested any reinfection (see the figure).

There were seven cases in which peak antibody titres ranged from 4 to 45 , and seven in which titres were between 64 and 1440; the durations of cold illnesses in the two groups were similar, but the bronchitic exacerbations ranged from 1 to 30 (average 14) days in the first group as compared with 14 to over 39 (average over 22) days in those with higher antibody levels. 
In the four patients who had more than one infection there was no evidence that the second or third infection induced any heterologous antibody response to the virus of a previous infection.

\section{Identity and characterisation of viruses}

The 14 rhinoviruses were tested with antisera against 52 of the first 56 agreed serotypes. Three strains were identified as types 7, 29 and 51 respectively (table II). Antisera were made against ten of the remaining 11 strains and used in cross-neutralisation tests (table III). The results indicate that the ten strains belong to eight different serotypes.

TABLE IV

Effects of various treatments on the titres of 8 candidate rhinoviruses

\begin{tabular}{|c|c|c|c|c|c|c|c|c|}
\hline \multirow{3}{*}{ Virus tested } & \multicolumn{8}{|c|}{$\log _{10}$ TCD50 per $0.2 \mathrm{ml}$ of virus suspensions tested as follows: } \\
\hline & \multicolumn{2}{|c|}{ Acid treatment * } & \multicolumn{2}{|c|}{$\begin{array}{l}\text { Chloroform } \\
\text { treatment } \dagger\end{array}$} & \multicolumn{2}{|c|}{ Filtration $\ddagger$} & \multicolumn{2}{|c|}{ BUDR treatment $\S$} \\
\hline & $\begin{array}{c}\text { control } \\
p \mathrm{H} 7\end{array}$ & $\begin{array}{c}\text { test } \\
p \mathrm{H} 4\end{array}$ & control & test & control & test & control & test \\
\hline $\begin{array}{r}409-62 \\
1321-62 \\
4704-62 \\
130-63 \\
1647-63 \\
1833-63 \\
4462-63 \\
1376-64\end{array}$ & $\begin{array}{l}4.0 \\
4.0 \\
3.5 \\
4.0 \\
3.5 \\
5.0 \\
3.5 \\
3.5\end{array}$ & $\begin{array}{l}<1.0 \\
<1.0 \\
<1.0 \\
<1.0 \\
<1.0 \\
2.0 \\
<1.0 \\
<1.0\end{array}$ & $\begin{array}{l}3.5 \\
1.5 \\
3.8 \\
2.5 \\
4 \cdot 2 \\
4 \cdot 2 \\
3.5 \\
4.2\end{array}$ & $\begin{array}{l}3 \cdot 8 \\
0 \cdot 8 \\
3 \cdot 8 \\
3 \cdot 2 \\
3 \cdot 8 \\
4 \cdot 5 \\
3 \cdot 2 \\
4 \cdot 2\end{array}$ & $\begin{array}{l}2.8 \\
5.5 \\
3.5 \\
2.8 \\
5.5 \\
4.2 \\
4.5 \\
4.5\end{array}$ & $\begin{array}{l}2.8 \\
2.5 \\
1.2 \\
2.2 \\
2.2 \\
1.8 \\
0.8 \\
2.5\end{array}$ & $\begin{array}{l}3 \cdot 5 \\
1.5 \\
3.8 \\
2.5 \\
4 \cdot 2 \\
4.2 \\
3.5 \\
4.2\end{array}$ & $\begin{array}{l}4.5 \\
2.2 \\
3.5 \\
1.8 \\
3.8 \\
4.5 \\
3.8 \\
4.5\end{array}$ \\
\hline
\end{tabular}

* Virus in citrate-citric acid buffer $p \mathrm{H} 4$ and in phosphate buffer $p \mathrm{H} 7$ (as control) for $1 \mathrm{hr}$ at $37^{\circ} \mathrm{C}$.

$\dagger 0.9 \mathrm{ml}$ virus with $0.1 \mathrm{ml}$ of chloroform for $5 \mathrm{~min}$. at room temperature.

\$ Filtration was through Gradocol membranes of average pore diameter $53 \mathrm{~m} \mu$ except for viruses 409-62 and 130-63 which were filtered through Millipore filters of $50 \mathrm{~m} \mu$ pore diameter.

$\S$ Bromodeoxyuridine in the test medium $(20 \mu \mathrm{g}$ per $\mathrm{ml})$ and control cultures in normal medium. (See Methods.)

A strain of each of these eight serotypes was then more fully characterised (table IV). Each was acid-labile, chloroform-stable, passed through a Millipore filter of $50 \mathrm{~m} \mu$ pore diameter or a Gradocol membrane of $53 \mathrm{~m} \mu$ average pore diameter and was not inhibited by bromodeoxyuridine. These properties indicate that these agents are small RNA viruses with the characteristics of rhinoviruses.

\section{Discussion}

Rhinoviruses have been isolated from chronic bronchitic patients in two of three studies in which they have been sought (Carilli, Gohd and Gordon, 1964; Eadie et al., 1966; Stenhouse, 1967). In both studies, rhinovirus infections were associated with exacerbations of bronchitis and this suggests that rhinoviruses might infect the lower respiratory tract in these cases. 
In our studies, rhinoviruses were isolated from the sputum on seven occasions, four times in the absence of detectable virus in the throat; this latter finding has been confirmed by Stenhouse who isolated two rhinoviruses from the sputum of two patients, but not from throat swabs or nasal washings taken at the same time. Titration of the rhinoviruses present in seven sputum specimens in the present study indicated that $120-120,000$ TCD50 of virus were present per ml. These quantities of virus are of the same order as the 32-160,000 TCD50 per ml that have been found in the nasal washings of volunteers inoculated with a rhinovirus (Douglas et al., 1966). However, it is difficult to estimate how much virus is shed in the nasal secretions, which are at an unknown dilution in a nasal washing, or in the bronchial secretions, which are usually diluted with an unknown amount of saliva in a sputum specimen. Nevertheless, the available evidence suggests that the concentrations of virus that we found in sputa were probably produced in the lower respiratory tract; it seems less likely that the virus was produced in the throat and " contaminated" the sputum.

The serological responses of the bronchitic patients to their rhinovirus infections provide further evidence that these infections were probably more severe and generalised than usual. Twelve of the 13 infections (nine of the ten $\mathrm{H}$-strain infections) that were associated with an exacerbation induced eight-fold or greater increases in neutralising antibody. This is a higher proportion of significant antibody responses than has been found in normal adults with colds in most other studies (Ketler, Hamparian and Hilleman, 1962; Taylor-Robinson et al., 1963; Gwaltney and Jordan, 1964) or in our studies of rhinovirus infections of children in hospital (unpublished observations). Some workers, however, have reported high proportions of significant antibody responses (Hamparian, Leagus and Hilleman, 1964; Phillips et al., 1965). Furthermore, in some of our cases the antibody level was not raised 15 days after the start of the cold, but it rose markedly after the exacerbation of bronchitis that usually followed the cold. These facts could be explained by the greater antigenic stimulus provided by a more severe and generalised infection. Consonant with this hypothesis is the observation that higher peak antibody titres were associated with bronchitic exacerbations of longer than average duration. Our finding of persistence of antibody for long periods after rhinovirus infections confirms the findings of other workers who studied similar infections in normal adults (Hamparian, Leagus, Hilleman and Stokes, 1964).

Three of the 14 rhinoviruses isolated belonged to recognised serotypes that were originally isolated from adults with colds. Antisera were made against ten of the remaining 11 strains and they were shown to belong to eight different serotypes. Strains of these eight serotypes have been further characterised and submitted as candidates for possibly new rhinovirus serotypes to $\mathrm{Dr} \mathrm{V}$. V. Hamparian and Dr R. Conant of Ohio State University. Two of these serotypes, 1647-63 and 1376-64 appear to have a greater affinity for human embryonic kidney fibroblasts than for human embryonic lung cells (Stott and Walker, 1967). Six of the eight possibly new serotypes were also found in non-bronchitic adults or children with acute respiratory illness in Glasgow between 1962 and 
1966 (unpublished observations); this indicates that the rhinoviruses that appear to cause such severe illness in chronic bronchitics are similar to those that cause mild upper respiratory illness in the general population.

\section{SUMMARY}

Rhinoviruses were isolated in 14 of 87 respiratory episodes that occurred in 24 of 44 patients with chronic bronchitis studied for periods up to $2 \frac{1}{2} \mathrm{yr}$. Thirteen of these infections were associated with exacerbations of bronchitis. The virus in seven rhinovirus-positive sputum specimens was assayed, and detailed studies of the neutralising antibody responses of the bronchitics to their rhinovirus infections were made. The results suggest that rhinoviruses multiply in the lower respiratory tract and probably stimulate a greater antibody response than that found in non-bronchitic adults. There was no evidence that the rhinoviruses found in the bronchitics were different from those circulating in the normal population. Three of the rhinoviruses belonged to known serotypes and ten of the remaining 11 belonged to eight other types. Representative strains of these eight types have been characterised and submitted as possibly new rhinovirus serotypes.

We wish to thank the bronchitic patients for their cooperation and Drs A. W. Lees, A. Clarke, W. Blair and W. K. Brown for helping us to select and allowing us to study the patients under their care.

We are grateful to Dr H. Williams of Raigmore Hospital, Inverness, for supplying human embryonic tissue, to Dr G. Appleyard of the Microbiological Research Establishment, Porton, for bromodeoxyuridine, and to the Wright-Fleming Institute for the Gradocol membranes. We are also indebted to Miss R. McLelland, Miss M. Walker and Mr G. Heath for valuable technical assistance, and we gratefully acknowledge a grant from the Secretary of State for Scotland.

\section{REFERENCES}

Carilli, A. D., Gohd, R. S. AND 1964. New Engl.J. Med., 270, 123.

GORDON, W.

Douglas, R. G., JR, Cate. T. R, 1966. Amer. Rev. Resp. Dis., 94, 159. Gerone, P. J., AND COUCH, R. B.

Eadie, Margaret B., Stott, E. J., AND 1966. Br. Med.J., 2, 671.

GRIST, N. R.

Grist, N. R., Ross, Constance A. C., 1966. Diagnostic methods in clinical virology, Bell, Eleanor J., AND Stott, E. J.

GWaltney, J. M., JR, AND JoRdan, 1964. Bact. Rev., 28, 409.

W. S., JR

Hamparian, V. V., Leagus, M. B., and Hilleman, M. R.

Hamparian, V. V., Leagus, M. B., 1964. Ibid., 117, 469. Hilleman, M. R., AND Stokes, J., JR

Hayflick, L., AND Moorhead, P. S. 1961. Expl Cell Res., 25585.

KAPIKIAN, 'A. Z., et al. . . . . . . 1967. Nature, Lond., 213, 761.

KäRBER, G,.. . . . . . . . 1931. Arch. exp. Path. Pharmak., 162, 480.

Ketler, A, Hamparian, V. V., And 1962. Proc. Soc. Exp. Biol. Med., 110, 821. Hilleman, $M . R$.

Phillips, C. A., Riggs, S., Melnick, 1965. J. Amer. Med. Assoc., 192, 277. 
Ross, Constance A. C., McMichael, S., 1966. Thorax, 21, 461. Eadie, Margaret B., Lees, A. W., Murray, E. A., ANd Pinkerton, I.

Stark, J. E., Heath, R. B., ANd Curwen, 1965. Ibid., 20, 124. M. P.

Stenhouse, A. C.

StotT, E. J., AND WALKer, M. .

TAYLOR-ROBINSON, D., JOHNSON, K. M., Bloom, H. H., Parrott, R. H., Mufson, M. A., AND ChANOCK, R. M.
1967. Br. Med.J., 3, 461.

1967. Br. J. Exp. Path., 48, 544.

1963. Amer. J. Hyg., 78, 285. 